\title{
Genetics of Leaf Rust Resistance in the Soft Red Winter Wheat Cultivars Coker 9663 and Pioneer 26R61
}

\author{
J. A. Kolmer, United States Department of Agriculture-Agricultural Research Service, Cereal Disease Laboratory, \\ St. Paul, MN 55108
}

\begin{abstract}
Kolmer, J. A. 2010. Genetics of leaf rust resistance in the soft red winter wheat cultivars Coker 9663 and Pioneer 26R61. Plant Dis. 94:628-632.

Leaf rust, caused by the fungus Puccinia triticina, is an important disease of soft red winter wheat cultivars that are grown in the southern and eastern United States. The objectives of this study were to identify the leaf rust resistance genes in two soft red winter wheat cultivars, Coker 9663 and Pioneer 26R61, that have been widely grown and were initially highly resistant to leaf rust. Both cultivars were crossed with the leaf-rust-susceptible spring wheat $\mathrm{cv}$. Thatcher and the $\mathrm{F}_{1}$ plants were crossed to Thatcher to obtain backcross $\left(\mathrm{BC}_{1}\right) \mathrm{F}_{2}$ families. In seedlings, the Thatcher/Coker $9663 \mathrm{BC}_{1} \mathrm{~F}_{2}$ families segregated for three independent seedling resistance genes when tested with different leaf rust isolates. The leaf rust infection types of selected $\mathrm{BC}_{1} \mathrm{~F}_{3}$ lines, when tested with different leaf rust isolates, indicated that seedling resistance genes $\operatorname{Lr} 9, \operatorname{Lr} 10$, and $\mathrm{Lr} 14 a$ were present. In field plot tests, $\mathrm{BC}_{1} \mathrm{~F}_{4}$ lines that were seedling susceptible had some adult plant resistance to leaf rust. Seedlings of the Thatcher/Pioneer 26R61 $\mathrm{BC}_{1} \mathrm{~F}_{2}$ families segregated for two independent resistance genes. Infection types of selected $\mathrm{BC}_{1} \mathrm{~F}_{3}$ lines indicated the presence of $L r 14 b$ and $L r 26$. The adult plant gene $L r 13$ was determined to be present in selected $\mathrm{BC}_{1} \mathrm{~F}_{4}$ lines that were tested with different leaf rust isolates in greenhouse tests.
\end{abstract}

Leaf rust, caused by Puccinia triticina Erikss., is the most common and widespread disease of wheat in the United States and worldwide (13). Soft red winter wheat cultivars are widely grown in the southern and eastern United States and have unique grain-quality characteristics that are suited for the production of cakes, cookies, and crackers. The soft red winter wheat cultivars have traditionally relied upon leaf rust resistance genes that are effective in seedlings. The comparison of seedling leaf rust infection types (ITs) produced on soft red winter wheat cultivars with ITs produced by the same $P$. triticina races on lines of wheat that differ for single leaf rust resistance genes allows for the postulation of seedling leaf rust resistance genes in these cultivars. Seedling resistance genes $L r 1, L r 2 a, L r 9, L r 10$, Lr11, Lr14a, Lr18, Lr24, and Lr26 have been postulated to be present in the soft red winter wheats (3). Genes $\operatorname{Lr} 12, \operatorname{Lr} 13$, $L r 34$, and $L r 46$ were derived from common hexaploid wheat and are most effective in the adult plant stage. Genes $\operatorname{Lr} 13$ and Lr34 are common in the hard red

Corresponding author: J. A. Kolmer

E-mail: jim.kolmer@ars.usda.gov

Accepted for publication 5 February 2010.

doi:10.1094/PDIS-94-5-0628

This article is in the public domain and not copyrightable. It may be freely reprinted with customary crediting of the source. The American Phytopathological Society, 2010. spring wheats $(6,10)$, and Lr46 has been described in CIMMYT wheats (15). Gene Lr12 is likely present in cv. Caldwell (1) and other soft red winter wheats. Genetic analysis to identify seedling and adult plant leaf rust resistance genes has rarely been conducted with soft red winter wheat cultivars. The expression of leaf rust resistance in adult plants in field plots is dependent upon the effectiveness of seedling and adult plant resistance genes. In most cases, gene postulation based on seedling ITs is not sufficient to determine which adult plant resistance genes may be present in a cultivar.

The objective of this study was to determine the identity of seedling and adult plant resistance genes in the soft red winter wheat cvs. Coker 9663 and Pioneer 26R61. These cultivars were grown over large areas in the southern United States and are from two important wheat breeding programs. Coker 9663 and Pioneer 26R61 were highly resistant to leaf rust in field plots in North Carolina in 2000 and were also postulated to differ for seedling leaf rust resistance genes (3). The pedigree of Coker 9663 is IN71761A431548/Fl302; and the pedigree of Pioneer 26R61 is Omega 78/S76/Arthur71/3/Stadler//Redocoat/Wisconsin 1/5/Coker 747/6/Pioneer 2555 sib.

\section{MATERIALS AND METHODS}

Seed of Coker 9663 and Pioneer 26R61 was planted in $15-\mathrm{cm}$-diameter pots that were filled with steamed topsoil and placed on a greenhouse bench with a mix- ture of fluorescent and incandescent lighting. After 10 days, when the plants were at the two-leaf stage, the pots were placed in a growth chamber with incandescent lighting at $10^{\circ} \mathrm{C}$ for 2 months of vernalization. After this period, the pots were placed in a growth cabinet with fluorescent and incandescent lighting with a 16-h day length at $18^{\circ} \mathrm{C}$. Pots with seed of the leaf-rustsusceptible spring wheat $\mathrm{cv}$. Thatcher (CI 1003) were placed in the growth cabinet 1 week before the Coker 9663 and Pioneer 26R61 plants were removed from the vernalization chamber and, at the same time, when the two soft red winter cultivars were placed in the growth cabinet. The Thatcher and soft red winter wheat plants were treated with Nutricot 13-13-13 NPK (Plantco Inc., Brampton, ON, Canada). At heading, the Thatcher plants were emasculated and pollen-shedding anthers from Coker 9663 and Pioneer 26R61 were used to pollinate the Thatcher female parents. The $F_{1}$ seed was harvested and then planted and vernalized for 1 month, and the $F_{1}$ plants were crossed as the male parent to Thatcher. Approximately 80 backcross $\left(\mathrm{BC}_{1}\right) \mathrm{F}_{1}$ seeds were obtained. The $\mathrm{BC}_{1} \mathrm{~F}_{1}$ seed were planted in a greenhouse in 15-cm-diameter pots and selfed to obtain $\mathrm{BC}_{1} \mathrm{~F}_{2}$ families.

In all, 15 to 20 seeds of each $\mathrm{BC}_{1} \mathrm{~F}_{2}$ family were planted in a $3.5-\mathrm{cm}^{2}$ plastic pot and inoculated when the primary leaves were fully expanded with different leaf rust isolates. The $P$. triticina isolates were identified by a four-letter code that describes virulence to a set of 16 nearisogenic lines of Thatcher wheat that have different leaf rust resistance genes (4). ITs of the nine $P$. triticina isolates used in this study to Thatcher lines with single genes for leaf rust resistance are given in Table 1. For seedling inoculations, rust urediniospores were mixed with Soltol 170 oil (Phillips Petroleum, Borger, OK) and then spray inoculated onto plants using the equipment and methods previously described (13). After inoculation, seedling plants were allowed to dry for $1 \mathrm{~h}$ and then placed in a mist chamber overnight at $18^{\circ} \mathrm{C}$ and $100 \%$ relative humidity. The seedlings were placed on a greenhouse bench after incubation. Seedlings were fertilized with a 20-20-20 NPK solution immediately after inoculation and at 14 days after planting. The ITs on the primary leaves of individual plants were read at 10 to 12 days after inoculation. The ITs were 
classified using a 0 -to-4 scale (9). ITs 0 (no visible sign of infection), ; (hypersensitive flecks), 1 (small uredinia surrounded by necrosis), and 2 (small moderate size uredinia surrounded by chlorosis) were considered to be low (resistant) and ITs from 3 (moderate size uredinia without necrosis or chlorosis) to 4 (large uredinia) were considered to be high (susceptible). Mixtures of ITs or mesothetic responses were indicated by listing the most common IT first, followed by the less common ITs. Larger and smaller uredinia were indicated by "+" and "-", respectively. $\mathrm{BC}_{1} \mathrm{~F}_{2}$ families that had only susceptible seedlings were considered to be homozygous susceptible and families that had both resistant and susceptible plants were considered to be segregating. The ratio of segregating to homozygous susceptible families was used to estimate the number of segregating resistance genes. A $\chi^{2}$ test (16) was used to determine whether the observed ratio significantly deviated from the expected ratio. The $\mathrm{BC}_{1} \mathrm{~F}_{3}$ lines derived from individual $\mathrm{BC}_{1} \mathrm{~F}_{2}$ plants selected for leaf rust resistance were tested for seedling resistance in the same manner as the $\mathrm{BC}_{1} \mathrm{~F}_{2}$ families. An $\mathrm{F}_{2}$ population of Thatcher/Pioneer 26R61 of approximately 120 individuals was tested for seedling resistance when the primary leaves were fully expanded.

In the field plot tests, 50 seeds of each genotype were planted in 2-m rows spaced $30 \mathrm{~cm}$ apart, perpendicular to rows of a mixture of wheat cvs. Thatcher, Morocco (PI 278386), Max (CI 15093), and Little Club (CI 4066) that are susceptible to leaf rust. The spreader rows and $\mathrm{BC}_{1} \mathrm{~F}_{2}$ families of Thatcher/Coker 9663 and Thatcher/ Pioneer 26R61 were inoculated in St. Paul, $\mathrm{MN}$ with a mixture of isolates MJBJ, THBJ, MCRK, TNRJ, and TDBG in 2005. In 2008, the spreader rows and selected Thatcher/Coker $9663 \mathrm{BC}_{1} \mathrm{~F}_{5}$ lines in St. Paul and Crookston, MN were inoculated with races MCDS, TDBG, MFPS, THBJ, and TNRJ. The adult plants were rated for leaf rust severity using the modified Cobb scale (11). Leaf rust response in the adult plants was rated as previously described (13). The field plots were rated for leaf rust when the susceptible cv. Thatcher had a leaf rust severity of 70 to $80 \%$ with a susceptible response.

For the greenhouse evaluation of adult plants, 4 seeds of each genotype were planted in a $15-\mathrm{cm}$ pot and grown in a greenhouse at 18 to $25^{\circ} \mathrm{C}$ with a 16 -h light period. Flag leaves of adult plants were inoculated in the same manner as in the seedling tests, with a mixture of urediniospores and oil. ITs were read 14 days after inoculation using the same IT scale as for the seedling tests. $\mathrm{BC}_{1} \mathrm{~F}_{2}$ plants from both crosses were evaluated for IT as adult plants, and seed from plants with low IT were selected and advanced by single-seed descent to $\mathrm{BC}_{1} \mathrm{~F}_{4}$ lines. $\mathrm{BC}_{1} \mathrm{~F}_{4}$ lines were tested for IT with different leaf rust isolates to postulate the identity of adult plant leaf rust resistance genes.

\section{RESULTS}

Seedlings of Thatcher/Coker 9663 $\mathrm{BC}_{1} \mathrm{~F}_{2}$ families segregated in a two-gene ratio when tested with isolate $\mathrm{BBBD}$ and for a single-gene ratio when tested with isolates THBJ, PNMR, and TLGF (Table 2). Segregation of $\mathrm{BC}_{1} \mathrm{~F}_{2}$ families to isolates THBJ, PNMR, and TLGF combined fit a 7:1 ratio that indicated that three different genes in Coker 9663 conditioned resistance to these isolates. Seedlings of Thatcher/Pioneer 26R61 $\mathrm{BC}_{1} \mathrm{~F}_{2}$ families segregated for a single gene to isolates BBBD and SBDG and all were homozygous susceptible to isolate THBJ. All $\mathrm{BC}_{1} \mathrm{~F}_{2}$ families that were homozygous susceptible to isolate SBDG were also homozygous susceptible to isolate BBBD, which indicated that the same gene in Pioneer 26R61 conditioned resistance to these isolates. Eighteen selected Thatcher/ Pioneer 26R61 $\mathrm{BC}_{1} \mathrm{~F}_{2}$ families that segregated or were homozygous susceptible to isolate BBBD segregated independently $(P$ $>0.05)$ for a different single gene when tested with isolate MCDS.

Seedling $\mathrm{BC}_{1} \mathrm{~F}_{2}$ plants from each cross were selected on the basis of low IT to each tested isolate and grown to maturity to obtain $\mathrm{BC}_{1} \mathrm{~F}_{3}$ lines for further seedling tests. Approximately $10 \mathrm{BC}_{1} \mathrm{~F}_{2}$ plants were selected from different families for each isolate. In the Thatcher/Coker $9663 \mathrm{BC}_{1} \mathrm{~F}_{3}$ lines (Table 3), lines 6 and 9 had low IT to

Table 2. Segregation of Thatcher*2/Coker 9663 and Thatcher*2/Pioneer $26 \mathrm{R} 61 \mathrm{BC}_{1} \mathrm{~F}_{2}$ families for leaf rust resistance in seedlings

\begin{tabular}{lccccc}
\hline & \multicolumn{2}{c}{$\mathbf{B C}_{\mathbf{1}} \mathbf{F}_{\mathbf{2}}$ families } & & & \\
\cline { 2 - 3 } Cross, leaf rust isolates & Segregating & Susceptible & Expected ratio & $\boldsymbol{\chi}^{\mathbf{2}}$ & $\boldsymbol{P}$ \\
\hline Thatcher*2/Coker 9663 & 61 & 23 & $3: 1$ & 0.25 & 0.61 \\
BBBD & 46 & 41 & $1: 1$ & 0.28 & 0.59 \\
THBJ & 38 & 50 & $1: 1$ & 1.64 & 0.20 \\
PNMR & 43 & 43 & $1: 1$ & 0.00 & 1.00 \\
TLGF & 73 & 11 & $7: 1$ & 0.03 & 0.87 \\
THBJ+PNMR+TLGF & & & & & \\
Thatcher*2/Pioneer 26R61 & 44 & 40 & $1: 1$ & 0.19 & 0.66 \\
BBBD & 0 & 83 & $0: 1$ & $\ldots$ & $\ldots$ \\
THBJ & 37 & 39 & $1: 1$ & 0.05 & 0.82 \\
SBDG & 11 & 7 & $1: 1$ & 0.89 & 0.35 \\
MCDS & & & &
\end{tabular}

Table 1. Seedling infection types (ITs) of 17 Thatcher (Tc) near-isogenic lines of wheat with single genes for leaf rust resistance to nine isolates of Puccinia triticina

\begin{tabular}{|c|c|c|c|c|c|c|c|c|c|}
\hline \multirow[b]{2}{*}{ Line } & \multicolumn{9}{|c|}{ IT produced by $P$. triticina isolates ${ }^{a}$} \\
\hline & BBBD & THBJ & PNMR & TLGF & SBDG & MCDS & MCRK & TCTD & MBRJ \\
\hline TcLrl & ; & $3^{+}$ & $3^{+}$ & $3^{+}$ & $3^{+}$ & $3^{+}$ & $3^{+}$ & $3^{+}$ & $3^{+}$ \\
\hline $\mathrm{Tc} L r 2 a$ & 0 & $3^{+}$ & $; 1^{+}$ & $3^{+}$ & $3^{+}$ & 0 & 0 & $3^{+}$ & 0 \\
\hline $\mathrm{Tc} L r 2 c$ & 0 & $3^{+}$ & $3^{+}$ & $3^{+}$ & $3^{+}$ & 0 & 0 & $3^{+}$ & 0 \\
\hline TcLr3a & ; & $3^{+}$ & $3^{+}$ & $3^{+}$ & ; & $3^{+}$ & $3^{+}$ & $3^{+}$ & $3^{+}$ \\
\hline $\operatorname{Tc} L r 9$ & 0 & $; 1^{=}$ & $3^{+}$ & $3^{+}$ & ; & ; & 0 & 0 & 0 \\
\hline TcLr16 & $; 1$ & $2+3$ & $1^{+}$ & $; 1^{-}$ & $; 1^{-}$ & 2 & $1^{+}$ & 2 & $1^{+}$ \\
\hline $\mathrm{Tc} L r 24$ & ; & ; & $3^{+}$ & ; & ; & 0 & 0 & ; & ; \\
\hline TcLr26 & ; & $3^{+}$ & ; & ; & $; 1=$ & $3^{+}$ & 3 & $3^{+}$ & ; \\
\hline TcLr3ka & $; 2^{-}$ & ;2 & $3^{+}$ & $; 2^{-}$ & ; & 2 & $3^{+}$ & 3 & $3^{+}$ \\
\hline TcLrl1 & $; 2^{-}$ & ;2 & $; 2^{-}$ & $3^{+}$ & $; 2^{-}$ & $2^{-}$ & $3^{+}$ & 3 & $3^{+}$ \\
\hline TcLr17 & $; 2^{-}$ & 2 & ; & $2^{+}$ & $3^{+}$ & 3 & $2^{=}$ & 3 & 2 \\
\hline TcLr30 & $; 2^{-}$ & $; 2=$ & 3 & ;2 & ; & $; 2^{-}$ & $3^{+}$ & 3 & $3^{+}$ \\
\hline $\mathrm{Tc} L r B$ & 2 & 2 & 3 & $2^{-}$ & $; 1^{-}$ & $3^{+}$ & 2 & 2 & 2 \\
\hline $\mathrm{Tc} L r 10$ & ; & $3^{+}$ & $3^{+}$ & ; & 3 & 3 & $3^{+}$ & ; & $3^{+}$ \\
\hline TcLrl4a & $3^{+}$ & $3^{+}$ & $; 12^{+}$ & $3^{+}$ & $; 12^{+}$ & $3^{+}$ & $3^{+}$ & 3 & $3^{+}$ \\
\hline $\mathrm{Tc} L r 14 b$ & $3^{+}$ & $3^{+}$ & 3 & $3^{+}$ & $3^{+}$ & ; & $3^{+}$ & ; & $3^{+}$ \\
\hline TcLrl8 & $; 2^{-}$ & $; 1^{=}$ & 3 & $3^{+}$ & $; 1^{-}$ & ; & $3^{+}$ & $; 2^{-}$ & $; 2^{-}$ \\
\hline
\end{tabular}

a Infection types as described by Long and Kolmer (9). 
isolates TLGF and BBBD, which indicated that these lines likely had gene $\operatorname{LrlO}$; lines 15 and 16 had high IT to isolates TLGF and PNMR, which indicated that these lines likely had $\operatorname{Lr} 9$; and lines 38 and 43 had low IT to PNMR, which indicated that these lines likely had LrI4a. In the Thatcher/Pioneer 26R61 $\mathrm{BC}_{1} \mathrm{~F}_{3}$ lines, lines 1 and 18 had low IT to isolate MCDS, which indicated that these lines likely have $L r 14 b$, and lines 3 and 13 had high IT to isolates THBJ and MCDS, which indicated that these lines likely have $L r 26$. Seedlings of Thatcher/Pioneer 26R61 $\mathrm{F}_{2}$ segregated 82 with IT ; (fleck) and 32 with IT $3^{+}$ which fit a single-gene $3: 1$ ratio $\left(\chi^{2}=0.57\right.$; $P=0.50)$ when tested with isolate MCDS that has high IT to Lr26. This single-gene segregation was likely due to $L r 14 b$.

The Thatcher/Coker $9663 \mathrm{BC}_{1} \mathrm{~F}_{2}$ families and the Thatcher/Pioneer 26R61 $\mathrm{BC}_{1} \mathrm{~F}_{2}$ families that were homozygous susceptible to isolate $\mathrm{BBBD}$ were tested for segregation of leaf rust resistance as adult plants in inoculated field plot tests. The $\mathrm{BC}_{1} \mathrm{~F}_{2}$ families from both crosses varied for leaf rust resistance, with rust severity varying from 10 to $80 \%$ in individual plants within families. However the
$\mathrm{BC}_{1} \mathrm{~F}_{2}$ families also varied considerably for maturity. Families with later maturity had lower leaf rust severity compared with families with earlier maturity. Because segregation for maturity confounded the expression of adult plant resistance in the field plot tests, all subsequent adult plant tests were conducted in greenhouse experiments with specific isolates of leaf rust. Coker 9663 and Pioneer 26R61 were negative when tested with the PCR based markers for Lr34 (8) and Lr46 (E. Lagudah, CSIRO Canberra, personal communication), which indicated that both cultivars lack these two adult plant leaf rust resistance genes.

In all, 19 Thatcher/Coker $9663 \mathrm{BC}_{1} \mathrm{~F}_{2}$ families and 22 Thatcher/Pioneer 26R61 $\mathrm{BC}_{1} \mathrm{~F}_{2}$ families that were susceptible to isolate $\mathrm{BBBD}$ in the seedling tests were tested as adult plants with isolate BBBD in greenhouse tests. In the Thatcher/Coker $9663 \mathrm{BC}_{1} \mathrm{~F}_{2}$ families, the IT ranged from $2^{+}$to $3^{+}$, with no hypersensitive low ITs present. Some of the individual $\mathrm{BC}_{1} \mathrm{~F}_{2}$ plants had relatively few uredinia compared with adult plants of Thatcher. In the Thatcher/Pioneer 26R61 BC $_{1} \mathrm{~F}_{2}$ families, the IT ranged from ;12 (hypersensitive flecks with small uredinia surrounded by chlorosis and necrosis) to $3^{+}$. In total, 11 Thatcher/Coker $9663 \mathrm{BC}_{1} \mathrm{~F}_{2}$ plants that had fewer uredinia compared with Thatcher were selected and advanced by single-seed descent to $\mathrm{BC}_{1} \mathrm{~F}_{4}$ lines, as were the 11 Thatcher/Pioneer 26R61 $\quad \mathrm{BC}_{1} \mathrm{~F}_{2}$ plants that had low IT of ;1-2. The 11 $\mathrm{BC}_{1} \mathrm{~F}_{4}$ plants that were selected for adult plant resistance from both crosses were tested as adult plants in greenhouse tests with isolates BBBD, TCTD, MCRK, and THBJ that differ for IT to the Thatcher lines with genes $L r 12$ and $L r 13$, and results for two lines from each cross are shown in Table 4. The Thatcher/Coker $9663 \mathrm{BC}_{1} \mathrm{~F}_{4}$ lines $36-2$ and 38 had IT of 3 to $3^{+}$to all four isolates, which indicated the lack of any hypersensitive adult plant resistance. Seed from lines 36-2 and 38 were advanced to $\mathrm{BC}_{1} \mathrm{~F}_{5}$ and evaluated for adult plant resistance in inoculated field plots in St. Paul and Crookston, MN. Lines 36-2 and 38 both had lower severity of uredinia surround by chlorosis compared with rows of the susceptible control Thatcher at both locations. The low IT of Thatcher/Pioneer 26R61 $\mathrm{BC}_{1} \mathrm{~F}_{4}$ lines 76-1 and 74 to isolates BBBD and TCTD indicated that these

Table 3. Seedling leaf rust infection types (ITs) of Thatcher*2/Coker $9663 \mathrm{BC}_{1} \mathrm{~F}_{3}$ and Thatcher*2/Pioneer $26 \mathrm{R} 61 \mathrm{BC}_{1} \mathrm{~F}_{3}$ lines to six isolates of Puccinia triticina

\begin{tabular}{|c|c|c|c|c|c|c|c|}
\hline \multirow[b]{2}{*}{ Line } & \multicolumn{6}{|c|}{ IT produced by $P$. triticina isolate $^{a}$} & \multirow[b]{2}{*}{ Gene } \\
\hline & TLGF & PNMR & BBBD & MBRJ & THBJ & MCDS & \\
\hline \multicolumn{8}{|l|}{ Thatcher*2/Coker $9663 \mathrm{~F}_{3}$} \\
\hline 6 & ; & $3^{+}$ & ; & $3^{+}$ & - & - & Lr10 \\
\hline 9 & ; & $3^{+}$ & ; & $3^{+}$ & - & - & Lr10 \\
\hline 15 & $3^{+}$ & $3^{+}$ & 0 & 0 & - & - & $\operatorname{Lr} 9$ \\
\hline 16 & $3^{+}$ & $3^{+}$ & 0 & 0 & - & - & $\operatorname{Lr} 9$ \\
\hline 38 & $3^{+}$ & $; 1$ & $3^{+}$ & $3^{+}$ & - & - & Lr14a \\
\hline 43 & $3^{+}$ & ;12 & $3^{+}$ & $3^{+}$ & - & - & Lr14a \\
\hline \multicolumn{8}{|c|}{ Thatcher*2/Pioneer 26R61 $\mathrm{F}_{3}$} \\
\hline 1 & 3 & $3^{+}$ & $2+3$ & $3^{+}$ & $3^{+}$ & ; & $\mathrm{Lr} 14 b$ \\
\hline 18 & $3^{+}$ & $3^{+}$ & $2+3$ & $3^{+}$ & $3^{+}$ & ; & $\operatorname{Lr} 14 b$ \\
\hline 3 & ; & $; 1^{-}$ & ; & $; 1^{-}$ & $3^{+}$ & $3^{+}$ & $\operatorname{Lr} 26$ \\
\hline 13 & ; & ; & ; & $; 1^{-}$ & $3^{+}$ & $3^{+}$ & $\operatorname{Lr} 26$ \\
\hline Thatcher $\operatorname{Lr} 9$ RL 6010 & $3^{+}$ & $3^{+}$ & ; & 0 & 0 & 0 & $\ldots$ \\
\hline Thatcher Lr10 RL 6004 & ; & $3^{+}$ & ; & $3^{+}$ & 3 & 3 & $\ldots$ \\
\hline Thatcher $\operatorname{Lr} 14 a$ RL6013 & $3^{+}$ & $; 1^{-}$ & $3^{+}$ & $3^{+}$ & 3 & 3 & $\ldots$ \\
\hline Thatcher $\operatorname{Lr} 14 b$ RL6056 & $3^{+}$ & $3^{+}$ & $3^{+}$ & $3^{+}$ & $3^{+}$ & ; & $\ldots$ \\
\hline Thatcher Lr26 RL6078 & ; & ; & ; & ; & $2+3$ & 3 & $\ldots$ \\
\hline
\end{tabular}

${ }^{\mathrm{a}}$ ITs as described by Long and Kolmer (9).

Table 4. Adult plant infection types (ITs), field rust severity, and response of Thatcher*2/Coker $9663 \mathrm{BC}_{1} \mathrm{~F}_{4}$ and Thatcher*2/Pioneer $26 \mathrm{R} 61 \mathrm{BC} \mathrm{F}_{4}$ lines and isogenic lines of Thatcher wheat with leaf rust resistance genes to four isolates of Puccinia triticina

\begin{tabular}{|c|c|c|c|c|c|c|c|}
\hline \multirow[b]{2}{*}{ Line } & \multicolumn{4}{|c|}{ IT produced by $P$. triticina isolate $^{\mathrm{a}}$} & \multicolumn{2}{|c|}{ Field rust severity and response ${ }^{b}$} & \multirow[b]{2}{*}{ Gene $^{\mathrm{c}}$} \\
\hline & BBBD & TCTD & MCRK & THBJ & St. Paul & Crookston & \\
\hline \multicolumn{8}{|c|}{ Thatcher*2/Coker $9663 \mathrm{BC}_{1} \mathrm{~F}_{4}$} \\
\hline $36^{-2}$ & $3^{+}$ & $33^{+}$ & $33^{+}$ & $3^{+}$ & $30 \mathrm{MS}$ & 50 MRMS & APR \\
\hline 38 & $3^{+}$ & $33^{+}$ & $3^{+}$ & $3^{+}$ & $50 \mathrm{MS}$ & $50 \mathrm{MS}$ & APR \\
\hline \multicolumn{8}{|c|}{ Thatcher*2/Pioneer 26R61 $\mathrm{BC}_{1} \mathrm{~F}_{4}$} \\
\hline $76^{-1}$ & ;2 & 0 & 3 & $3^{+}$ & $\ldots$ & $\ldots$ & Lr13 \\
\hline 74 & 0 & 0 & $3^{+}$ & $3^{+}$ & $\ldots$ & $\ldots$ & Lr13 \\
\hline Thatcher & $3^{+}$ & $3^{+}$ & $3^{+}$ & $3^{+}$ & $80 \mathrm{~S}$ & $70 \mathrm{~S}$ & $\ldots$ \\
\hline Thatcher Lr13 RL4031 & $; 1^{-}$ & $; 2^{-}$ & $3^{+}$ & $3^{+}$ & 70MRS & $50 \mathrm{~S}$ & $\ldots$ \\
\hline
\end{tabular}

a ITs as described by Long and Kolmer (9).

${ }^{\mathrm{b}}$ Rust severity measured on a modified Cobb scale (11). MR = moderately resistant, medium to large uredinia surrounded by necrosis; MS $=$ moderately susceptible, medium to large uredinia surrounded by chlorosis; and $\mathrm{S}=$ susceptible, large uredinia without necrosis or chlorosis.

${ }^{c} \mathrm{APR}=$ adult plant resistance. 
lines likely have $L r 13$. Isolate TCTD also produces a low IT of ; 1 to $L r 14 b$. The low IT of 0 ; of the $\mathrm{BC}_{1} \mathrm{~F}_{4}$ lines $76-1$ and 74 to TCTD is likely due to the presence of both Lr13 and Lr14b. The Thatcher line with Lrl3 conditioned a small degree of resistance relative to Thatcher in field plots at St. Paul and had slightly lower severity compared with Thatcher in plots at Crookston. Lines 76-1 and 74 both had high IT to isolate MCRK, which has a low IT to the adult plant gene Lr12, which indicated that neither of these lines have Lr12.

\section{DISCUSSION}

Coker 9663 was determined to likely have $\operatorname{Lr} 9, \operatorname{Lr} 10, \operatorname{Lr} 14 a$, and some undefined adult plant resistance. The field leaf rust resistance of Coker 9663 was directly related to the effectiveness of $\operatorname{Lr} 9$ and Lr10. In the 1990s, many soft red winter wheat cultivars were postulated to have $\operatorname{Lr} 9$ (3); however, relatively few current soft red winter wheat cultivars have this gene (J. A. Kolmer, unpublished data). Virulence to $\operatorname{Lr} 9$ increased steadily in the $P$. triticina population in the southeastern states starting in 1998, reaching nearly $50 \%$ of isolates in 2001 (4). However, in the late 1990s, many of the isolates with virulence to $\operatorname{Lr} 9$ were race TLGF (2), which is avirulent to Lr10. During this time, Coker 9663 would have been resistant to TLGF in part due to the effectiveness of Lr10. Gene LrI4a has also been postulated to be in the soft red winter wheat cultivars (1) (J. A. Kolmer, unpublished data); however, virulence to this gene in the $P$. triticina population in the southeast has been very common and Lr14a would not be expected to condition any effective resistance. Coker 9663 was widely grown in the late 1990s throughout the mid-south and southeastern states. In 2000, Coker 9663 was highly resistant to leaf rust in field plots in North Carolina (3). However, by 2003, as races with virulence to $\operatorname{Lr} 9$ and $\operatorname{Lr} 10$ increased, Coker 9663 was considered to be susceptible to leaf rust and was no longer widely grown. Although Coker 9663 has some adult plant nonhypersensitive resistance, by itself it was not sufficient to condition a useful level of resistance for a released cultivar.

Pioneer 26R61 was determined to likely have $L r 13, L r 14 b$, and $L r 26$. In the 1990s (3) and currently (J. A. Kolmer, unpublished data), Lr26 was postulated to be present in a small number of soft red winter wheat cultivars. In the southeastern states, virulence to $\operatorname{Lr} 26$ has varied between less than $5 \%$ in 2001 to $70 \%$ in 2007 (5). Lrl3 is an adult plant gene that conditions race-specific resistance. In the southeastern United States, most of the current races of $P$. triticina have virulence to $\operatorname{Lrl3}$ (2), which has limited its effectiveness. Lr13 may also be present in other soft red winter wheats. Roelfs (12) indi- cated that the Brazilian cvs. Frondosa and Supreza were sources of Lrl3 for the soft red winter wheats and that Redcoat and Atlas 66 may have Lr13. Lrl4b is not widely found in any wheat class in North America and, because nearly all isolates of $P$. triticina are virulent to this gene, it is unlikely that $L r 14 b$ contributes to the effective resistance in Pioneer 26R61. Although virulence to Lr13 and Lr26 is common in the $P$. triticina population in the United States, it would appear that the field resistance of Pioneer 26R61 is due to these two resistance genes, because no other effective seedling or adult plant resistance was detected in this cultivar. Pioneer 26R61 was widely grown in the southern states in the late 1990s and continues to be grown in Georgia. The leaf rust resistance in Pioneer 26R61 has remained relatively stable, because it has been rated as resistant to moderately resistant in recent field plot tests at various locations (2007-2008 Uniform Southern Winter Wheat Nurseries: http: www.ars.usda.gov/main/docs. htm?docid=2925), although, in some locations, it was rated as moderately susceptible. Isolates of $P$. triticina with virulence to $\operatorname{Lr} 13$ and Lr26 may not be evenly distributed across the southeastern region, which may explain why Pioneer 26R61 has been considered resistant and susceptible at different locations in the same year.

In a previous study (3), Coker 9663 was postulated to have $\operatorname{Lr} 2 a, \operatorname{Lr} 9$, and $\operatorname{Lr} 10$ on the basis of ITs with different $P$. triticina isolates. In that study, an isolate that was virulent to $\operatorname{Lr} 9$ was also low to $\operatorname{Lr} 2 a$ and Lrl4a. Similarly, in the same study, Pioneer 26R61 was postulated to have Lr11 and Lr26. In the previous study, the isolates that were virulent to $L r 26$ were also virulent to Lr11. Direct postulation of combinations of $L r$ genes in wheat cultivars by IT of different $P$. triticina isolates is limited by the virulence phenotypes of the available isolates. In this study, $\mathrm{BC}_{1} \mathrm{~F}_{2}$ families and $\mathrm{BC}_{1} \mathrm{~F}_{3}$ derived lines that segregated for single genes were used to identify the leaf rust resistance genes, rather than by direct postulation of the wheat cultivars.

Lr9 has been an important component of leaf rust resistance in soft red winter wheats. This gene was derived from Triticum umbellulata L. and was initially used in cvs. Riley 67 and Arthur 71, released in 1967 and 1971, respectively (14). Although derived from a wild relative of wheat, $\operatorname{Lr} 9$ has not provided long-lasting resistance because races of $P$. triticina with virulence to this gene were found soon after the release of these cultivars. However, virulence to $\operatorname{Lr} 9$ often declines rapidly after the replacement of wheat cultivars with this gene, suggesting some fitness cost associated with virulence to Lr9. Similarly, Lr26 located on the 1B-1R wheat-rye translocation has not provided long-lasting resistance because leaf rust races with virulence to this gene have increased in the United States and other countries after cultivars with the wheat-rye translocation were released. However, similar to $\operatorname{Lr} 9$, races with virulence to $\operatorname{Lr} 26$ often gradually decline after the removal of cultivars with this gene. Thus, the effectiveness of $\operatorname{Lr} 9$ and $\operatorname{Lr} 26$ may be somewhat cyclical, depending on whether races with virulence to these genes are increasing or decreasing.

Development of soft red winter wheat cultivars that have long-lasting resistance will require combinations of leaf rust resistance genes that have conditioned effective resistance over a number of years. In the hard red spring wheats, combinations of Lr16, Lr23, and Lr34 have provided effective, durable resistance despite the relatively poor resistance conditioned by the genes individually $(6,10)$. Effective adult plant leaf rust resistance has been characterized in the winter wheats Caldwell (1) and CI13227 (17). These adult plant resistances could be combined with sources of Lr34 such as Sturdy, Bezostaya1, and Sumai 3 (7) to develop cultivars with highly effective adult plant resistance that may prove to be durable over time.

\section{ACKNOWLEDGMENTS}

I thank M. Grabowski and K. Xiao for technical assistance.

\section{LITERATURE CITED}

1. Kolmer, J. 2009. Genetics of leaf rust resistance in the soft red winter wheat 'Caldwell'. Crop Sci. 49:1187-1192.

2. Kolmer, J. A. 2002. Virulence phenotypes of Puccinia triticina in the South Atlantic States in 1999. Plant Dis. 86:288-291.

3. Kolmer, J. A. 2003. Postulation of leaf rust resistance genes in selected soft red winter wheats. Crop Sci. 43:1266-1274.

4. Kolmer, J. A., Long, D. L., and Hughes, M. E. 2008. Physiologic specialization of Puccinia triticina on wheat in the United States in 2006. Plant Dis. 92:1241-1246.

5. Kolmer, J. A., Long, D. L., and Hughes, M. E. 2009. Physiologic specialization of Puccinia triticina on wheat in the United States in 2007. Plant Dis. 93:538-544.

6. Kolmer, J. A., and Oelke, L. M. 2006. Genetics of leaf rust resistance in the spring wheats 'Ivan' and 'Knudson'. Can. J. Plant Pathol. 28:223-229.

7. Kolmer, J. A., Singh, R. P., Garvin, D. F. Viccars, L., William, H. M., Huerta-Espino, J. H., Obonnaya, F. C., Raman, H., Orford, S., Bariana, H. S., and Lagudah, E. S. 2008. Analysis of the $L r 34 / Y r 18$ rust resistance region in wheat germplasm Crop Sci. 48:18411852.

8. Lagudah, E. S., McFadden, H., Singh, R. P., Huerta-Espino, J., Bariana, H. S., and Spielmeyer, W. 2006. Molecular characterization of the $\operatorname{Lr} 18 / \mathrm{Yr} 18$ slow rusting resistance gene region in wheat. Theor. Appl. Genet. 114:21-30

9. Long, D. L., and Kolmer, J. A. 1989. A North American system of nomenclature for Puccinia recondita f. sp. tritici. Phytopathology 79:525-529.

10. Oelke, L. M., and Kolmer, J. A. 2005. Genetics of leaf rust resistance in spring wheat cultivars Norm and Alsen. Phytopathology 95:773-778.

11. Peterson, R. F., Campbell, A. B., and Hannah, 
A. E. 1948. A diagrammatic scale for estimating rust intensity on leaves and stems of cereals. Can. J. Res. Sect. C 26:496-500.

12. Roelfs, A. P. 1988. Resistance to leaf and stem rusts in wheat. Pages 10-22 in: Breeding Strategies for Resistance to the Rusts of Wheat. N. W. Simmonds and S. Rajaram, eds. CIMMYT, Mexico, D.F.

13. Roelfs, A. P., Singh, R. P., and Saari, E. E.
1992. Rust Diseases of Wheat: Concepts and Methods of Disease Management. CIMMYT, Mexico, D.F.

14. Shaner, G., Roberts, J. J., and Finney, R. E. 1972. A culture of Puccinia recondita virulent to the wheat cultivar Transfer. Plant Dis. Rep. 56:827-830.

15. Singh, R. P., Mujeebkazi, A., and Huerta Espino, J. 1998. Lr46 - a gene conferring slow rusting resistance to leaf rust in wheat. Phytopathology 88:890-894.

16. Steel, R. D., and Torrie, J. H. 1980. Principles and Procedures of Statistics. McGraw Hill Book Co., New York.

17. $\mathrm{Xu}, \mathrm{X}$. , Bai, G., Carver, B., Shaner, G. E., an Hunger, R. M. 2005. Molecular characterization of slow leaf rusting resistance in wheat. Crop Sci. 45:758-765. 